liaison among African studies centres, staffing and equipment for research and teaching, and co-ordination and exchange of bibliographical and other documentation. Separate sessions were also held to consider priorities in research and opportunities for co-ordination between centres in Western Africa and in Central and Eastern Africa.

A number of recommendations made at the various sessions were considered by the Conference as a whole at its closing session. A fuller report of the Conference will be given in a later number of Africa.

\title{
Institute Research Grants
}

A LIMITED number of grants will be offered by the Institute in 1964 to assist the completion of research in progress within the scope of its recognized field of studies, i.e. African ethno$\operatorname{logy}$, sociology, and linguistics. The value of the grants will range between $£ 250$ and $£ 750$ according to circumstances.

The grants are intended to assist with funds for the extension of a period of field research already in progress, field expenses for a short period to complete an earlier field investigation, or the preparation for publication of the results of previous field research. They will not include funds for overseas travel or the purchase of major items of equipment.

Relevant universities and research centres have already received notification of this research grants programme. The awards will be made by the end of September 1964, and details of the grants will appear in the January ig6s issue of Africa.

\section{African Studies at the University of Chicago}

A Committee on African Studies has been formed at the University of Chicago to promote and co-ordinate research and graduate training in African studies through the departments and schools represented by the members of the Committee, who are: C. Arnold Anderson (education); Allison Dunham (law); Lloyd A. Fallers (anthropology); Philip J. Foster (education); Donald N. Levine (sociology); Robert A. LeVine (human development), Chairman; Grant McConnell (political science); Ronald Singer (anatomy and anthropology); Marc J. Swartz (anthropology); Gilbert F. White (geography); Aristide Zolberg (political science).

\section{The Linguistic Association of Liberia}

The Linguistic Association of Liberia was founded in January 1964 at Cuttington College, Suakoko, Liberia. Representatives of several mission organizations and of the University of Liberia were present at the founding meeting. Professor John Gay and Mr. John Wealar, both of Cuttington College, were elected President and Secretary-Treasurer respectively, and Professor Wm. E. Welmers of the University of California, Los Angeles, Liaison Secretary. The purpose of the Association is to provide facilities for intercommunication among, and technical assistance to, researchers in the languages of Liberia, including Liberian forms of English and English as a second language, and also to provide for more effective communication between the small linguistic community within Liberia and the more extensive community of linguistic scholarship in other parts of Africa and the rest of the world. Dues for the first year of the Association's operations were set at $\$ 2.00$, student members being exempted. It is expected that these dues will be spent largely in starting a collection of materials on and literature in the indigenous languages of Liberia, many of which materials exist only in mimeographed or other duplicated form.

Communications concerning the Association may be addressed to Mr. John Wealar, Cuttington College, c/o Bishop's House, Monrovia, Liberia, or Professor Wm. E. Welmers, University of California, Near Eastern and African Languages, Los Angeles 24, California. 